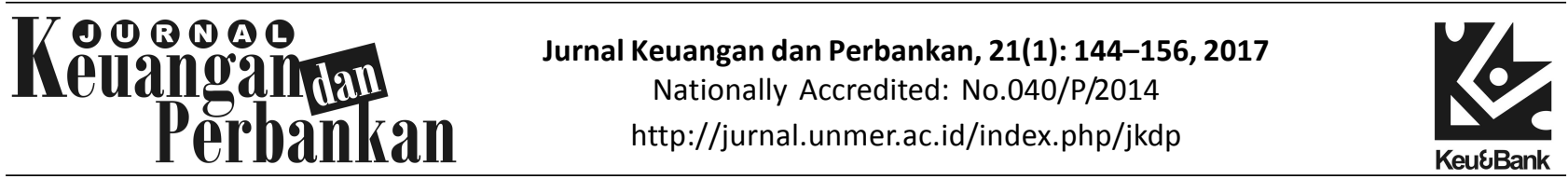

\title{
LOYALITAS NASABAH DAN KINERJA PERBANKAN DI INDONESIA
}

\author{
Nurul Aisyah Rachmawati ${ }^{1}$, Lindawati Gani ${ }^{2}$, Hilda Rossieta ${ }^{2}$ \\ ${ }^{1}$ Departemen Akuntansi Fakultas Ekonomi Bisnis dan Humaniora Universitas Trilogi \\ Jl. TMP Kalibata No.1 Jakarta, 12760, Indonesia \\ ${ }^{2}$ Departemen Akuntansi Fakultas Ekonomi dan Bisnis Universitas Indonesia \\ Kampus UI Depok, 16424, Indonesia
}

\section{Keywords: \\ Consumer Loyalty, Financial Perfor- mance, Market Perfomance, Non- Financial Perfor- mance}

\section{Abstract}

The purpose of this study was to investigate the impact of customer loyalty on firm performance in the banking industry in Indonesia. This study used sample of banking firms listed on the Indonesian Stock Exchange. The data was processed and analyzed by Partial Least Square (PLS). We hypothesized that firm's financial performance, market performance, and non-financial performance were positively affected by customer loyalty. The results provided an evidence which was consistent with the hypothesis. It showed that customer loyalty provided incremental information to the firm's performance that consisted of financial performance, market performance, and nonfinancial performance.
Kata Kunci: Loyalitas Nasabah, Kinerja

Perusahaan, Kinerja Pasar, Kinerja NonFinansial

\section{Abstrak}

Penelitian ini bertujuan untuk menginvestigasi dampak loyalitas nasabah terhadap kinerja perusahaan pada industri perbankan di Indonesia. Penelitian ini menggunakan sampel perusahaan perbankan yang terdaftar di Bursa Efek Indonesia (BEI). Data diolah dan dianalisis dengan Partial Least Square (PLS). Penelitian ini menduga bahwa kinerja keuangan, kinerja pasar, dan kinerja non-keuangan perbankan dipengaruhi secara positif oleh loyalitas nasabah. Hasil penelitian memberikan bukti yang konsisten dengan dugaan tersebut. Hasil penelitian menunjukkan bahwa loyalitas nasabah memberikan incremental information terhadap kinerja perbankan yang terdiri dari kinerja keuangan, kinerja pasar, dan kinerja non-keuangan. 
Perbankan merupakan suatu industri yang sangat menggantungkan pendapatan bisnisnya terhadap loyalitas nasabahnya. Loyalitas nasabah diduga dapat memberikan incremental information terhadap kinerja perusahaan dalam industri perbankan, dibandingkan hanya sekadar kepuasan nasabah. Kepuasan nasabah saja disinyalir tidak cukup untuk menjelaskan kinerja perusahaan di industri perbankan.

Sampai dengan saat ini, informasi keuangan menuai kritikan lantaran kurang mampu memberikan informasi yang relevan bagi manajer mengenai kondisi bisnis perusahaan terkini. Informasi keuangan sebagaimana tersaji dalam laporan keuangan hanya menyajikan transaksi historis per usahaan, sehingga tidak dapat menangkap adanya perubahan environment dengan cepat (Johnson \& Kaplan, 1987; Simons, 1990) dan kurang dapat digunakan untuk memprediksi kinerja keuangan perusahaan di masa depan (Ittner \& Larcker, 1998).

Untuk mendapatkan informasi yang relevan, manajer juga harus mempertimbangkan ukuran non-finansial agar lebih memahami faktor-faktor yang memengaruhi kinerja perusahan (Leo et al., 2009). Fisher (1992) menyatakan bahwa manajer seringkali mempertimbangkan informasi nonkeuangan yang disinyalir lebih informatif dibandingkan dengan informasi keuangan. Informasi non-keuangan mampu menyajikan informasi terkini mengenai aktivitas perusahaan dan juga konsekuensi ekonomis masa depan atas tindakan manajer (Fisher, 1992). Informasi non-keuangan seringkali membantu manajer untuk mengidentifikasi adanya critical activities yang memerlukan perhatian lebih pada saat mengelola perusahaan (Cooper \& Kaplan, 1991). Dengan demikian, manajer cenderung menganggap bahwa informasi nonkeuangan lebih actionable dan forward-looking dibandingkan dengan informasi keuangan (Fisher, 1992).

Salah satu ukuran non-keuangan yang mampu memberikan informasi yang relevan mengenai kondisi bisnis perusahaan terkini adalah loyalitas pelanggan. Loyalitas pelanggan dapat lebih memberikan incremental information dibandingkan dengan kepuasan pelanggan. Loyalitas pelanggan merupakan faktor penting untuk memastikan adanya pengulangan pembelian oleh pelanggan (Caruana, 2002; Gupta \& Zeithaml, 2006). Bahkan loyalitas pelanggan tidak hanya mampu meningkatkan nilai dalam bisnis perusahaan, tetapi juga dapat menarik pelanggan baru (Beerli et al., 2004).

Penelitian ini bertujuan untuk menguji apakah loyalitas nasabah berpengaruh positif terhadap kinerja perbankan di Indonesia. Penelitian ini memberikan 3 kontribusi dalam pengembangan literatur yang menguji dampak loyalitas pelanggan terhadap kinerja perusahaan. Kontribusi pertama, penelitian ini mencoba untuk mengembangkan penelitian sebelumnya dengan menguji dampak loyalitas nasabah terhadap kinerja perusahaan pada industri perbankan. Industri perbankan memiliki dimensi kinerja yang berbeda jika dibandingkan dengan industri lainnya. Industri perbankan memiliki peranan yang vital dalam pertumbuhan ekonomi di Indonesia. Pasalnya, perbankan memberikan kemudahan dan fleksibilitas bagi pelaku pasar dalam mengelola dana (Bank Indonesia, 2014).

Penelitian yang menguji dampak loyalitas pelanggan terhadap kinerja bisnis perusahaan masih terbatas. Beberapa penelitian sebelumnya telah menguji loyalitas nasabah di industri perbankan, namun tidak dikaitkan dengan kinerja perusahaan (Siddiqi, 2011; Kheng et al., 2010). Dalam pengujiannya, Siddiqi (2011) fokus pada hubungan antara kualitas pelayanan, kepuasan nasabah, dan loyalitas nasabah pada sektor perbankan di Bangladesh. Hal serupa dilakukan oleh Kheng et al. (2010) pada industri perbankan di Penang, Malaysia.

Penelitian mengenai pengaruh loyalitas pelanggan terhadap kinerja bisnis perusahaan masih terfokus pada industri selain perbankan (Reichheld \& Sasser, 1990; Soeling, 2007). Dalam studi 
Reichheld \& Sasser (1990) ditemukan bahwa loyalitas pelanggan memiliki korelasi yang positif dengan kinerja bisnis perusahaan. Soeling (2007) menyatakan bahwa upaya peningkatan loyalitas pelanggan dapat memperbaiki kinerja perusahaan, baik dalam jangka pendek maupun jangka panjang. Dalam jangka pendek, loyalitas pelanggan mampu meningkatkan profit perusahaan. Dalam jangka panjang, loyalitas pelanggan dapat digunakan untuk managing customer, sehingga akan memberikan keuntungan lebih pada perusahaan. Dalam hal ini, pelanggan yang loyal akan bersedia membayar dengan harga yang lebih tinggi atau dengan adanya penyediaan layanan yang murah, pelanggan yang loyal bersedia merekomendasikan kepada calon pelanggan.

Loyalitas nasabah diduga juga berpengaruh positif terhadap kinerja perusahaan di industri perbankan. Untuk mencapai kinerja tertentu, bank harus berlomba-lomba meningkatkan loyalitas nasabahnya. Di Indonesia, persaingan antar bank kian lama kian ketat. Hal ini dilakukan sebagai upaya untuk berebut nasabah dan mempertahankan loyalitas nasabah yang ada. Oleh sebab itu, bank rela mengeluarkan biaya yang tidak sedikit untuk mempertahankan dan meningkatkan loyalitas nasabahnya, misalnya dengan berlomba-lomba menyelenggarakan program gebyar hadiah (Infobank Edisi 394, 2012; Bolton et al., 2000). Kualitas pelayanan yang prima memang merupakan sesuatu yang wajib dimiliki oleh bank, namun hal itu tidak serta merta dapat menjadikan nasabah berkomitmen dan loyal untuk menggunakan produk dan layanan yang diberikan oleh bank.

Kontribusi kedua, penelitian ini mempertimbangkan beberapa informasi non-keuangan yang merupakan faktor penentu loyalitas nasabah. Berdasarkan hasil survei independen yang dilakukan oleh MarkPlus Inc bekerjasama dengan Majalah Infobank, informasi non-keuangan yang dimaksud adalah tingkat kepuasan nasabah (customer satisfaction index), tingkat transaksi nasabah (customer transaction index), tingkat hubungan nasabah (customer relationship index), dan tingkat kemitraan nasabah (customer partnership index). Beberapa faktor penentu loyalitas nasabah tersebut diduga merupakan faktor penting untuk memastikan adanya pengulangan pembelian oleh pelanggan. Karena tidak hanya mampu meningkatkan nilai dalam bisnis perusahaan, tetapi juga dapat menarik pelanggan baru (Caruana, 2002; Beerli et al., 2004; Griffin, 2005; Kotler, 2005; Gupta \& Zeithaml, 2006).

Kontribusi ketiga, penelitian ini menggunakan beberapa indikator ukuran kinerja perbankan, yaitu ukuran kinerja keuangan, ukuran kinerja pasar, dan ukuran kinerja non-keuangan. Penggunaan beberapa ukuran kinerja ini dilakukan untuk meningkatkan validitas hasil yang dilaporkan dalam penelitian. Penelitian sebelumnya seringkali hanya menggunakan ukuran kinerja finansial saja (Ittner \& Larcker, 1998; Fornell et al., 2006; Leo et al., 2009).

Sesuai dengan Gani \& Jermias (2012), penelitian ini menggunakan 4 variabel kinerja finansial yang didasarkan pada angka akuntansi (accounting-based) yang juga digunakan oleh Bank Indonesia untuk mengevaluasi kinerja bank di Indonesia. Keempat variabel tersebut adalah return on assets (ROA), return on equity (ROE), net interest margin (NIM), dan non-performing loans (NPL).

Merchant \& Van der Stede (2007) menyatakan bahwa ukuran kinerja perusahaan yang didasarkan pada angka akuntansi (seperti ROA) cenderung berada di bawah kontrol manajer. Dengan demikian, ukuran kinerja tersebut lebih mudah untuk dimanipulasi oleh manajer, dibandingkan dengan ukuran kinerja yang didasarkan pada nilai pasar. Untuk mengatasi persoalan ini, penelitian ini juga menggunakan ukuran kinerja yang didasarkan pada pasar (market-based). Leo et al. (2009) serta Ittner \& Larcker (1998) membuktikan bahwa kepuasan pelanggan berpengaruh positif terhadap ukuran kinerja pasar perusahaan. Pasalnya, kepuasan pelanggan mampu meningkatkan arus kas dan 
menurunkan risiko arus kas, sehingga menyebabkan saham perusahaan lebih menarik bagi investor (Leo et al., 2009). Mengingat loyalitas nasabah juga dibentuk dari kepuasan nasabah, maka penelitian ini juga menggunakan market-to-book ratio (MTB) dan market value (MVE) sebagai proksi ukuran kinerja yang didasarkan pada pasar (marketbased) sesuai dengan penelitian Leo et al. (2009) dan Ittner \& Larcker (1998).

Sebagai pelengkap, penelitian ini juga menggunakan ukuran kinerja non-keuangan, yaitu Indonesia Bank Loyalty Index (IBLI) pada tahun berikutnya. IBLI merupakan hasil survei independen dari MarkPlus Inc bekerjasama dengan Majalah Infobank. Dalam penyusunan IBLI tersebut, Mark Plus Inc dan Majalah Infobank mempertimbangkan 4 faktor, yaitu customer satisfaction (transaction), customer retention (relationship), migration barrier (partnership), dan customer enthusiasm (ownership).

Beberapa penelitian menunjukkan bahwa indikator ukuran kinerja non- keuangan yang penting pada bank adalah kepuasan pelanggan (Venkatraman \& Ramanujam, 1987; Rhee \& Mehra, 2006; Gani \& Jermias, 2012). Oleh karena salah satu indikator penyusun IBLI adalah kepuasan pelanggan, maka penelitian ini menggunakan IBLI tahun berikutnya sebagai proksi ukuran kinerja non-keuangan. Penelitian ini menduga faktorfaktor penentu loyalitas nasabah tahun ini akan berdampak positif terhadap IBLI tahun berikutnya. Alasannya, loyalitas pelanggan merupakan faktor penting untuk memastikan adanya pengulangan pembelian oleh pelanggan karena tidak hanya mampu meningkatkan nilai dalam bisnis perusahaan, tetapi juga dapat menarik pelanggan baru (Caruana, 2002; Beerli, et al., 2004; Griffin, 2005; Kotler, 2005; Gupta \& Zeithaml, 2006).

\section{PENGEMBANGAN HIPOTESIS}

Berdasarkan kajian konsep dan empiris di atas, maka ditarik hipotesis sebagai berikut:

$\mathrm{H}_{1}$ : loyalitas nasabah berpengaruh positif terhadap ukuran kinerja perbankan.

\section{METODE}

Penelitian ini fokus pada industri perbankan karena industri ini sangat menggantungkan pendapatan bisnisnya terhadap loyalitas nasabahnya. Industri perbankan memiliki dimensi kinerja yang berbeda jika dibandingkan dengan industri lainnya. Industri perbankan memiliki peranan yang vital dalam pertumbuhan ekonomi di Indonesia. Pasalnya, perbankan memberikan kemudahan dan fleksibilitas bagi pelaku pasar dalam mengelola dana (Bank Indonesia, 2014). Penelitian yang menguji dampak loyalitas nasabah terhadap kinerja perbankan masih terbatas. Tabel 1 menyajikan hasil pemilihan sampel yang digunakan dalam penelitian ini.

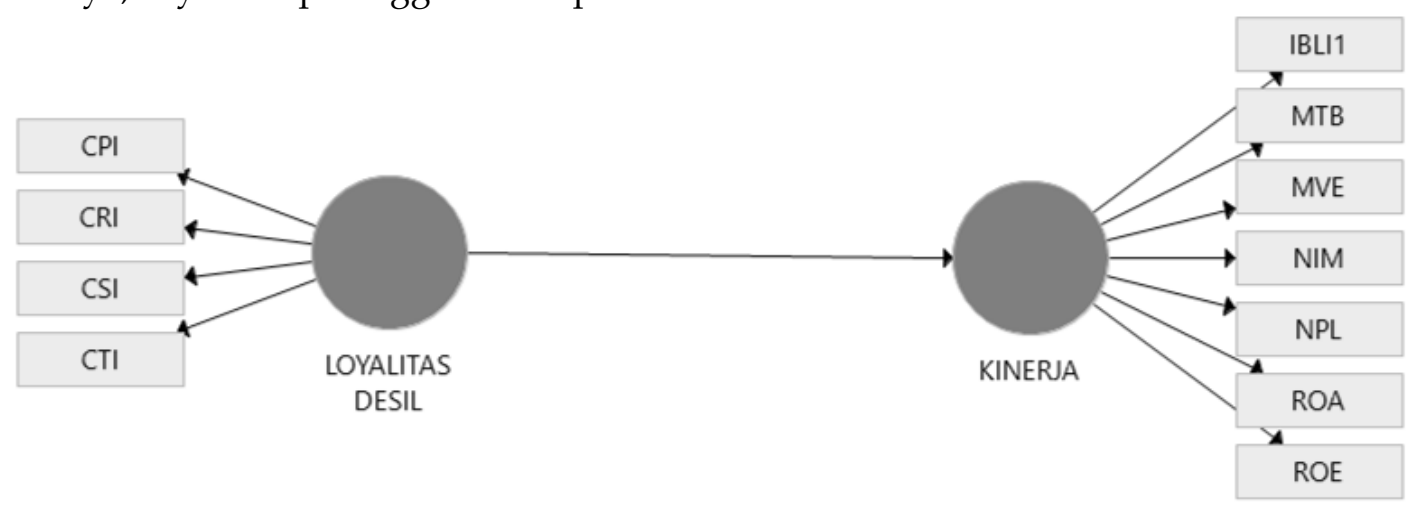

Gambar 1. Kerangka Pemikiran 
Oleh karena jumlah sampel dalam penelitian ini terbatas, maka data diolah dan dianalisis dengan Partial Least Square (PLS) menggunakan software SmartPLS 3. Sebelum melakukan pengujian hipotesis, penelitian ini terlebih dahulu melakukan pengujian validitas dan reliabilitas untuk memastikan apakah data yang digunakan valid dan reliabel.

Periode penelitian ini dimulai dari tahun 2007-2013. Pemilihan sampel didasarkan pada metode purposive sampling. Penelitian ini memilih sampel bank yang memenuhi kriteria berikut: (1) Bank memiliki data faktor-faktor penentu loyalitas nasabah, yaitu tingkat kepuasan nasabah (customer satisfaction index), tingkat transaksi nasabah (customer transaction index), tingkat hubungan nasabah (customer relationship index), dan tingkat kemitraan nasabah (customer partnership index), yang dipublikasikan pada Majalah Infobank Edisi 394 (Januari 2012), Edisi 406 (Januari 2013), dan Edisi 418 (Januari 2014). Pada edisi tersebut, dapat diketahui data faktor-faktor penentu loyalitas nasabah dari survei yang dilakukan pada tahun 2007-2013. Periode ini mengindikasikan periode terkini dari hasil survei yang dilakukan oleh MarkPlus Inc bekerjasama dengan Majalah Infobank. Sementara itu, hasil survei sudah tidak dipublikasikan lagi pada periode Januari 2015 dan Januari 2016; (2) Bank telah terdaftar pada BEI dan mempublikasikan laporan keuangan pada periode penelitian, yaitu 2007-2013; dan (3) Bank memiliki data pasar yang diperlukan dalam penelitian.
Sesuai dengan hipotesis yang dikembangkan, berikut ini adalah estimasi model penelitian yang digunakan untuk menguji $\mathrm{H}_{1}$ :

Kinerja $_{i}=\alpha_{0}+\alpha_{1}$ Loyalitas_Desil $_{i}+\varepsilon_{i}$

Keterangan:

Kinerja $_{i}$

$=$ kombinasi antara ukuran kinerja keuangan, ukuran kinerja pasar, dan ukuran kinerja non-keuangan untuk perusahaan $i$.

Loyalitas_Desil $_{i}=$ kombinasi antara faktor-faktor penentu loyalitas nasabah untuk perusahaan i.

Dalam mengukur loyalitas nasabah, Mark Plus Inc dan Majalah Infobank mempertimbangkan 4 faktor, yaitu customer satisfaction (transaction), customer retention (relationship), migration barrier (partnership), dan customer enthusiasm (ownership). Berdasarkan Majalah Infobank edisi 394 (Januari 2012), nasabah yang loyal karena puas terhadap produk yang digunakan dikategorikan sebagai kelompok rational loyalist. Sementara itu, nasabah yang loyal karena retention program dan migration barrier dikategorikan sebagai kelompok emotional loyalist. Atas dasar ini, penulis akan menguji dampak rational loyalist (yang disusun atas CSI dan CTI) terhadap kinerja perbankan dan dampak emotional loyalist (yang disusun atas CRI dan CPI) terhadap kinerja perbankan. Pengujian ini baik dilakukan secara terpisah maupun bersama-sama. Hal ini

Tabel 1. Pemilihan Sampel

\begin{tabular}{lcc}
\hline & \multicolumn{1}{c}{ Keterangan } & Jumlah Observasi \\
\hline Perusahaan-tahun yang data faktor-faktor penentu loyalitas nasabahnya & 161 \\
dipublikasikan pada Majalah Infobank & & \\
Perusahaan-tahun yang tidak memiliki data faktor-faktor penentu loyalitas & $(22)$ \\
nasabah secara lengkap & & $(57)$ \\
Perusahaan-tahun yang tidak terdaftar di BEI & $(2)$ \\
Perusahaan-tahun yang tidak memiliki data pasar secara lengkap & $\mathbf{8 0}$ \\
\hline Jumlah sampel akhir & & \\
\hline
\end{tabular}


dilakukan untuk mengetahui manakah di antara kelompok rational loyalist dan emotional loyalist yang lebih berpengaruh terhadap kinerja perbankan.

Penelitian ini juga melakukan robustness test untuk memastikan apakah model penelitian robust atau tidak. Dalam hal ini, penulis mengganti variabel loyalitas_desil dengan variabel IBLI pada periode survei. Data IBLI ini diperoleh dari hasil survei MarkPlus Inc dan Majalah Infobank. Skor indeks tersebut kemudian diranking dari yang terkecil hingga yang terbesar. Setelah itu, indeks tersebut dibagi ke dalam sub-sampel desil. Setiap sub-sampel desil diberi kode 1 untuk desil terkecil berurutan hingga 10 untuk desil terbesar. Kode tersebut kemudian diproporsionalkan sehingga nilai setiap indeks berada di antara 0 dan 1 (dengan cara besaran kode dikurangi 1 dan dibagi 9). Nilai akhir inilah yang digunakan untuk menggantikan konstruk variabel loyalitas_desil perusahaan.

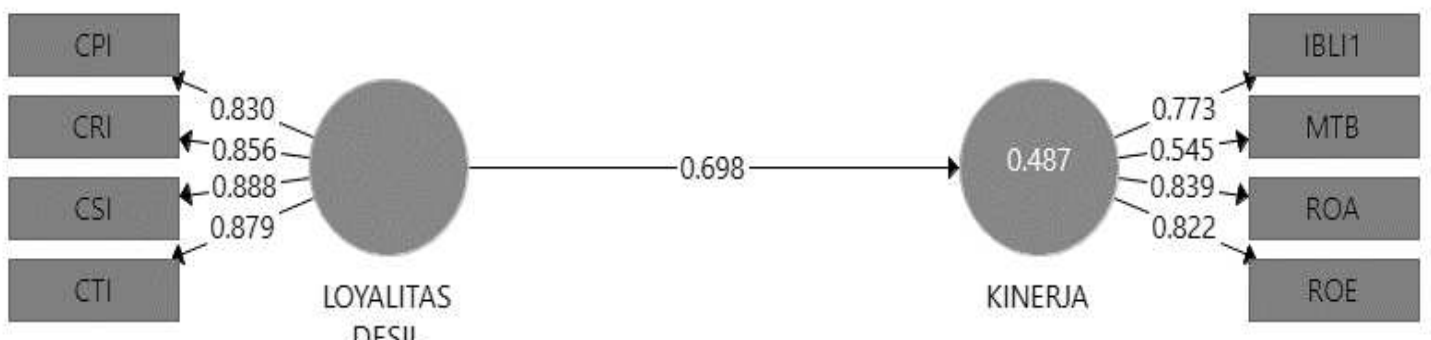

Gambar 2. Loading Factor

Tabel 2. Hasil Pengujian Validitas

\begin{tabular}{lccc}
\hline Variabel Laten & Indikator & Loading Factor & Keterangan \\
\hline Loyalitas_Desil & CSI & 0,888 & Valid \\
& CTI & 0,879 & Valid \\
& CRI & 0,856 & Valid \\
\multirow{4}{*}{ Kinerja } & CPI & 0,830 & Valid \\
& IBLI1 & 0,773 & Valid \\
& MTB & 0,545 & Valid \\
& ROA & 0,839 & Valid \\
& ROE & 0,822 & Valid \\
\hline
\end{tabular}

Keterangan:

Loyalitas_Desil = kombinasi antara faktor-faktor penentu loyalitas nasabah

CSI $=$ Customer Satisfaction Index

$\mathrm{CTI}=$ Customer Transaction Index

CRI = Customer Relationship Index

$\mathrm{CPI} \quad=$ Customer Partnership Index

Kinerja = kombinasi antara ukuran kinerja keuangan, ukuran kinerja pasar, dan ukuran kinerja non-keuangan

IBLI1 = Indonesia Bank Loyalty Index setelah periode survei

MTB = Market-to-Book Ratio

ROE $\quad=$ Return on Equity

ROA = Return on Assets 


\section{HASIL}

Pengujian validitas dilakukan untuk memvalidasi apakah setiap indikator yang digunakan untuk mengukur variabel laten memiliki tingkat validitas yang baik. Menurut Hussein (2015), suatu indikator dapat dikatakan memiliki tingkat validitas yang baik, apabila memiliki nilai loading factor yang lebih besar atau sama dengan 0,5. Berdasarkan hasil pengujian validitas yang dilakukan, ternyata tidak semua indikator yang digunakan untuk membentuk variabel laten valid. Dalam hal ini, NIM, NPL, dan MVE memiliki nilai loading factor yang kurang dari 0,5. Jadi, indikator yang tidak valid tersebut harus dikeluarkan dari pengukuran. Gambar 2 dan Tabel 2 adalah hasil pengujian validitas untuk variabel loyalitas_desil dan kinerja yang valid dan digunakan dalam penelitian ini.

Berdasarkan Tabel 2, diketahui bahwa seluruh indikator variabel loyalitas_desil valid dan digunakan dalam penelitian ini. Pada variabel ini, indikator yang memiliki loading factor tertinggi adalah CSI. Hal ini sesuai dengan penelitian sebelumnya yang menyatakan bahwa kepuasan pelanggan merupakan salah satu informasi non-keuangan yang paling penting dan menjadi kunci utama untuk menciptakan loyalitas pelanggan (Kaplan \& Norton, 1996). Perusahaan yang mampu memuaskan pelanggannya, akan lebih cenderung mampu mengikat (retain) pelanggan yang dimilikinya, meningkatkan customer profitability, dan mendapatkan pelanggan yang baru. Dengan demikian, ke- puasan pelanggan juga merupakan isu penting yang dapat digunakan untuk meningkatkan loyalitas pelanggan dan selanjutnya dapat memperbaiki kinerja bisnis (Gronholdt et al., 2000).

Sementara itu, untuk variabel kinerja hanya dibentuk oleh indikator IBLI1 sebagai proksi dari ukuran kinerja non-keuangan, MTB sebagai proksi dari ukuran kinerja pasar, serta ROA dan ROE sebagai proksi ukuran kinerja keuangan. Di antara keempat indikator tersebut, yang memiliki nilai loading factor tertinggi adalah ROA dan yang memiliki nilai loading factor terendah adalah MVB.

Pengujian reliabilitas dilakukan untuk memastikan apakah variabel yang digunakan dalam penelitian ini reliabel. Tabel 3 menyajikan hasil pengujian reliabilitas. Berdasarkan Tabel 3 tersebut diketahui bahwa variabel loyalitas_desil dan kinerja memiliki nilai composite reliability lebih dari 0,7 , nilai average variance extracted (AVE) lebih dari 0,5 , dan nilai cronbach alpha lebih dari 0,6. Hal ini mengindikasikan bahwa tidak ditemukan adanya permasalahan reliabilitas pada model yang dibentuk.

Tabel 4 Panel A dan Panel B menunjukkan hasil statistik deskriptif dan correlation matrix atas data yang digunakan dalam penelitian ini. Berdasarkan Tabel 4 Panel A diketahui bahwa rata-rata indikator CSI, CTI, CRI, dan CPI yang menyusun variabel loyalitas_desil adalah 75,36, $74,99,74,23$, dan 71,10. Sementara itu, rata-rata indikator IBLI1, MTB, ROE, dan ROA yang menyusun variabel kinerja adalah 73,03, 0,82, 0,19, dan 0,02 .

Tabel 3. Hasil Pengujian Reliabilitas

\begin{tabular}{lccc}
\hline \multicolumn{1}{c}{ Variabel Laten } & Composite Reliability & AVE & Cronbach Alpha \\
\hline Loyalitas_Desil & 0,921 & 0,745 & 0,886 \\
Kinerja & 0,837 & 0,569 & 0,740 \\
\hline
\end{tabular}

Keterangan:

Loyalitas_Desil $=$ kombinasi antara faktor-faktor penentu loyalitas nasabah

Kinerja $\quad$ kombinasi antara ukuran kinerja keuangan, ukuran kinerja pasar, dan ukuran kinerja non-keuangan 
Tabel 4 Panel B menyajikan pearson correlations antara indikator yang menyusun variabel loyalitas_desil dan kinerja. Berdasarkan Tabel 4 Panel $B$ tersebut diketahui bahwa hampir seluruh indikator yang menyusun loyalitas_desil (CSI, CTI, CRI, dan CPI) berhubungan positif dan signifikan terhadap seluruh indikator yang menyusun kinerja (IBLI1, MTB, ROE, dan ROA). Hanya CTI dan CPI yang memiliki hubungan lemah dengan MTB. Namun demikian, hasil correlation matrix ini merupakan indikasi awal adanya hubungan yang kuat antara variabel loyalitas_desil dan kinerja.
Tabel 5 menyajikan hasil pengujian hipotesis. Sebagaimana dijelaskan sebelumnya, pengujian hipotesis dilakukan beberapa kali. Pertama, menguji apakah loyalitas_desil berpengaruh positif terhadap kinerja. Kedua, variabel loyalitas_desil dipecah menjadi 2, yaitu rational loyalist dan emotional loyalist yang diuji baik secara terpisah maupun bersama-sama. Jika dilihat pada Tabel 5 Panel A, B, C, dan D, diketahui bahwa nilai SRMR untuk masing-masing regresi sebesar 0,112, 0,129, 0,125 , dan 0,110 . Oleh karena nilai SRMR

Tabel 4. Statistik Deskriptif dan Correlation Matrix

\begin{tabular}{lcccc}
\hline \multicolumn{2}{l}{ Panel A - Statistik Deskriptif $\mathbf{( n = 8 0 )}$} & & & \\
\hline Minimum & Maksimum & Mean & Standard Deviation \\
\hline CSI & 70,80 & 83,90 & 75,36 & 2,42 \\
CRI & 69,10 & 84,00 & 74,99 & 2,67 \\
CPI & 65,90 & 81,50 & 74,23 & 3,01 \\
IBLI1 & 65,50 & 77,00 & 71,10 & 2,64 \\
MTB & 67,20 & 78,10 & 73,03 & 2,41 \\
ROE & 0,00 & 3,68 & 0,82 & 0,89 \\
ROA & 0,01 & 0,44 & 0,19 & 0,09 \\
& 0,00 & 0,05 & 0,02 & 0,01
\end{tabular}

\begin{tabular}{lrrrrrrrr}
\hline \multicolumn{7}{l}{ Panel B - Pearson Correlations } \\
\hline \multicolumn{2}{c}{ CSI } & CTI & CRI & CPI & IBLI1 & MTB & ROE & ROA \\
\hline$C S I$ & $\mathbf{1 , 0 0}$ & & & & & & & \\
$C T I$ & $\mathbf{0 , 4 6}$ & 1,00 & & & & & & \\
$C R I$ & $\mathbf{0 , 5 7}$ & $\mathbf{0 , 5 9}$ & 1,00 & & & & & \\
$C P I$ & $\mathbf{0 , 6 2}$ & $\mathbf{0 , 3 6}$ & $\mathbf{0 , 4 8}$ & 1,00 & & & & \\
$I B L I 1$ & $\mathbf{0 , 6 8}$ & $\mathbf{0 , 4 0}$ & $\mathbf{0 , 3 4}$ & $\mathbf{0 , 4 0}$ & 1,00 & & & \\
$M T B$ & $\mathbf{0 , 3 1}$ & 0,19 & $\mathbf{0 , 3 5}$ & 0,22 & 0,14 & 1,00 & & \\
$R O E$ & $\mathbf{0 , 2 9}$ & $\mathbf{0 , 3 9}$ & $\mathbf{0 , 4 2}$ & $\mathbf{0 , 4 2}$ & 0,09 & $\mathbf{0 , 2 5}$ & 1,00 & \\
ROA & $\mathbf{0 , 3 4}$ & $\mathbf{0 , 4 1}$ & $\mathbf{0 , 4 1}$ & $\mathbf{0 , 4 7}$ & 0,16 & 0,22 & $\mathbf{0 , 8 8}$ & \\
\hline
\end{tabular}

Keterangan:

Bold menunjukkan hubungan yang signifikan pada level kepercayaan $99 \%$

CSI = Customer Satisfaction Index

CTI = Customer Transaction Index

$\mathrm{CRI}=$ Customer Relationship Index

$\mathrm{CPI}=$ Customer Partnership Index

IBLI1 = Indonesia Bank Loyalty Index setelah periode survei

$\mathrm{MTB}=$ Market-to-Book Ratio

ROE = Return on Equity

ROA = Return on Assets 
mendekati 0, maka hal tersebut mengindikasikan bahwa model memiliki good fit.

Berdasarkan Tabel 5 Panel A diketahui bahwa variabel loyalitas_desil memiliki pengaruh yang positif dan signifikan terhadap variabel kinerja. Hal ini ditunjukkan dengan nilai t-statistik yang lebih besar dari t-tabel dan $p$-value yang lebih kecil dari alpha $1 \%$. Ini berarti bahwa loyalitas nasabah sebagai proksi dari informasi non-keuangan memiliki pengaruh yang kuat terhadap kinerja perbankan. Tidak dapat dipungkiri, perbankan merupakan suatu industri yang sangat menggantungkan pendapatan bisnisnya terhadap loyalitas nasabahnya.

Dalam Tabel 5 Panel B, C, dan D juga diketahui bahwa ketika loyalitas nasabah dibedakan menjadi 2, yaitu rational loyalist dan emotional loyalist yang diuji baik secara terpisah maupun bersamasama, hasil pengujian tidak berubah. Dalam hal ini, variabel rational loyalist dan emotional loyalist juga berpengaruh positif dan signifikan terhadap variabel kinerja, baik yang diuji secara terpisah maupun bersama-sama. Dengan demikian, hipotesis $1\left(\mathrm{H}_{1}\right)$ terbukti (diterima).

Namun, hasil pengujian akan tetap lebih baik ketika variabel loyalitas-_desil diuji secara utuh (tidak dipecah). Hal ini dapat dibuktikan dari besarnya adjusted $R^{2}$ sebagaimana tersaji dalam Tabel 5. Dari tabel tersebut diketahui bahwa nilai adjusted $R^{2}$ tertinggi berada pada model struktural loyalitas_desil $\rightarrow$ kinerja, yaitu sebesar 0,481. Hal ini berarti bahwa kemampuan variabel loyalitas_desil dalam menjelaskan variable kinerja adalah sebesar $48,1 \%$. Dengan kata lain, 51,9\% dari variabel kinerja dijelaskan oleh variabel lain di luar model. Sementara itu, model struktural yang ada pada Tabel 5 Panel B, C, dan D lebih kecil dari 0,481.

Tabel 5. Model Struktural Pengujian Hipotesis

\begin{tabular}{lccc}
\hline \multicolumn{1}{c}{ Jalur } & $\begin{array}{c}\text { Loading } \\
(\boldsymbol{t} \text {-statistik })\end{array}$ & Adjusted $\boldsymbol{R}^{2}$ & Model Fit \\
\hline $\begin{array}{l}\text { Panel A } \\
\text { Loyalitas_Desil } \rightarrow \text { Kinerja }\end{array}$ & $\begin{array}{c}0,698 \\
(27,702)^{* * *}\end{array}$ & 0,481 & SRMR $=0,112$ \\
$\begin{array}{l}\text { Panel B } \\
\text { Rational Loyalist } \rightarrow \text { Kinerja }\end{array}$ & 0,679 & 0,454 & SRMR $=0,129$ \\
Panel C & $(29,458)^{* * *}$ & & SRMR $=0,125$ \\
Emotional Loyalist $\rightarrow$ Kinerja & 0,616 & 0,372 & \\
Panel D & $(22,162)^{* * *}$ & & SRMR $=0,110$ \\
Rational Loyalist $\rightarrow$ Kinerja & 0,262 & 0,478 & \\
Emotional Loyalist $\rightarrow$ Kinerja & $(5,426)^{* * *}$ & & \\
& $(10,898)^{* * *}$ & & \\
\hline
\end{tabular}

Keterangan:*,**,*** adalah signifikan pada level kepercayaan $90 \%, 95 \%, 99 \%$.

Variabel endogen $=$ kinerja

Kinerja = kombinasi antara ukuran kinerja keuangan, ukuran kinerja pasar, dan ukuran kinerja non-keuangan

Loyalitas_Desil = kombinasi antara faktor-faktor penentu loyalitas nasabah

Rational Loyalist = nasabah yang loyal karena puas terhadap produk yang digunakan

Emotional Loyalist = nasabah yang loyal karena retention program dan migration barrier 
Tabel 6 menyajikan hasil robustness test terkait pengujian pengaruh loyalitas nasabah terhadap kinerja perbankan. Berdasarkan tabel tersebut diketahui bahwa nilai SRMR sebesar 0,133. Hal tersebut mengindikasikan bahwa model memiliki "good fit". Dalam Tabel 6 juga diketahui bahwa variabel IBLI memiliki pengaruh yang positif dan signifikan terhadap variabel kinerja. Hal ini ditunjukan dengan nilai t-statistik yang lebih besar dari t-tabel dan $p$ value yang lebih kecil dari alpha $1 \%$. Oleh karena hasil pengujian pada Tabel 6 tidak berbeda dari Tabel 5, maka ini berarti bahwa model penelitian robust.

\section{PEMBAHASAN}

Sesuai dengan tujuan penelitian, hasil menunjukkan bahwa kinerja perusahaan yang berada pada industri perbankan sangat tergantung pada loyalitas nasabahnya. Dalam hal ini, loyalitas nasabah yang merupakan kombinasi atas tingkat kepuasan nasabah, tingkat transaksi nasabah, tingkat hubungan nasabah, dan tingkat kemitraan mampu meningkatkan baik kinerja keuangan, kinerja pasar, dan kinerja non-keuangan perbankan.

Hasil penelitian ini mengindikasikan bahwa loyalitas nasabah memberikan incremental information terhadap kinerja perbankan, dibandingkan hanya sekadar kepuasan nasabah. Hasil penelitian ini menunjukkan bahwa kepuasan nasabah saja tidak cukup untuk menjelaskan kinerja perusahaan di industri perbankan. Selain kepuasan nasabah, perbankan juga perlu menjaga hubungan dan kemitraan dengan nasabahnya. Jadi wajar saja jika bank rela mengeluarkan biaya yang tidak sedikit untuk mempertahankan dan meningkatkan loyalitas nasabahnya serta untuk mencapai kinerja tertentu, misalnya dengan berlomba-lomba menyelenggarakan program gebyar hadiah (Infobank Edisi 394, Januari 2012; Bolton et al., 2000). Kualitas pelayanan yang prima memang merupakan sesuatu yang wajib dimiliki oleh bank (Siddiqi, 2011; Kheng et al., 2010). Namun demikian, hal itu tidak serta merta dapat menjadikan nasabah lebih berkomitmen dan loyal untuk menggunakan produk dan layanan yang diberikan oleh bank.

Hasil pengujian hipotesis ini mendukung studi sebelumnya (Reichheld \& Sasser, 1990; Soeling, 2007). Dalam studi Reichheld \& Sasser (1990) ditemukan bahwa loyalitas pelanggan memiliki korelasi yang positif dengan kinerja bisnis perusahaan. Soeling (2007) menyatakan bahwa upaya peningkatan loyalitas pelanggan dapat memperbaiki kinerja perusahaan, baik dalam jangka pendek maupun jangka panjang. Dalam jangka pendek, loyalitas pelanggan mampu meningkatkan profit perusahaan. Dalam jangka panjang, loyalitas pelanggan dapat digunakan untuk managing customer, sehingga akan memberikan keuntungan lebih pada perusahaan.

Hal ini selaras dengan karakteristik loyalitas pelanggan yang merupakan faktor penting untuk memastikan adanya pengulangan pembelian oleh

Tabel 6. Hasil Robustness Test

\begin{tabular}{cccc}
\hline Jalur & Loading $($ t-statistik) & Adjusted $\mathbf{R}^{2}$ & Model Fit \\
\hline$I B L I \rightarrow$ Kinerja & $0,613(19,550)^{* * *}$ & 0,367 & SRMR $=0,133$ \\
\hline
\end{tabular}

Keterangan:*,**,*** adalah signifikan pada level kepercayaan $90 \%, 95 \%, 99 \%$

Variabel endogen $=$ kinerja

Kinerja $\quad$ kombinasi antara ukuran kinerja keuangan, ukuran kinerja pasar, dan ukuran kinerja non-keuangan

Loyalitas_Desil = kombinasi antara faktor-faktor penentu loyalitas nasabah

IBLI $\quad=$ Indonesia Bank Loyalty Index pada periode survei 
pelanggan karena tidak hanya mampu meningkatkan nilai dalam bisnis perusahaan, tetapi juga dapat menarik pelanggan baru (Caruana, 2002; Beerli, et al., 2004; Griffin, 2005; Kotler, 2005; Gupta \& Zeithaml, 2006). Berdasarkan karakteristik tersebut, indikator CSI, CTI, CRI, dan CPI memang tidak dapat dipisahkan satu sama lain. Sesuai dengan prediksi sebelumnya, loyalitas nasabah memberikan incremental information terhadap kinerja perusahaan dalam industri perbankan, dibandingkan hanya sekedar kepuasan nasabah.

Penelitian ini juga menunjukkan bahwa hasil temuan masih tetap konsisten meskipun komponen loyalitas telah dibedakan menjadi dua, yaitu: (1) Rational loyalist, di mana loyalitas nasabah didasarkan pada kepuasan terhadap produk yang digunakan; dan (2) Emotional loyalist, dimana loyalitas nasabah didasarkan pada retention program dan migration barrier. Dalam hal ini, rational loyalist dan emotional loyalist juga mampu meningkatkan kinerja perbankan, baik ketika diuji secara individu maupun bersama-sama.

Di antara kedua komponen loyalitas tersebut, rational loyalist disinyalir lebih memiliki kemampuan untuk merepresentasikan kinerja perbankan relatif dibandingkan dengan emotional loyalist. Selaras dengan penelitian terdahulu bahwa kepuasan pelanggan merupakan indikator ukuran kinerja non-keuangan yang penting pada bank (Venkatraman \& Ramanujam, 1987; Rhee \& Mehra, 2006; Gani \& Jermias, 2012). Meskipun demikian, hasil pengujian rational loyalist dan emotional loyalist sacara bersama-sama atau tanpa memisahkan komponen loyalitas masih menunjukkan pengaruh yang paling besar terhadap kinerja perbankan.

\section{SIMPULAN DAN SARAN}

\section{Simpulan}

Penelitian ini bertujuan untuk menginvestigasi dampak loyalitas nasabah terhadap kinerja perusahaan pada industri perbankan di Indone- sia. Perbankan merupakan suatu industri yang sangat menggantungkan pendapatan bisnisnya terhadap loyalitas nasabahnya. Sesuai dengan hasil penelitian ini, loyalitas nasabah memiliki pengaruh yang kuat terhadap kinerja perbankan. Semakin tinggi loyalitas nasabah di suatu bank, maka semakin tinggi kinerja bank tersebut.

Penelitian ini juga membuktikan bahwa hasil pengujian lebih baik ketika faktor-faktor penyusun loyalitas (yang terdiri dari tingkat kepuasan nasabah, tingkat transaksi nasabah, tingkat hubungan nasabah, dan tingkat kemitraan) diuji secara utuh (tidak dipecah menjadi rational loyalist dan emotional loyalist). Namun demikian, jika dibandingkan dengan indikator-indikator yang menyusun variabel loyalitas_desil, kepuasan nasabah masih menjadi informasi non-keuangan yang paling penting dan menjadi kunci utama untuk menciptakan loyalitas nasabah (Kaplan \& Norton, 1996).

\section{Saran}

Berikut ini adalah beberapa keterbatasan penelitian yang dapat dijadikan pertimbangan untuk penelitian selanjutnya. Pertama, penelitian ini menggunakan sampel yang terbatas karena Majalah Infobank hanya mempublikasikan IBLI, CSI, CTI, CRI, dan CPI untuk bank yang berada pada urutan 10 besar saja pada setiap kategori bank, di antaranya bank dengan aset Rp100 triliun ke atas, bank dengan aset di bawah Rp100 triliun, dan bank syariah, serta 5 besar untuk kategori bank pembangunan daerah. Selain itu, jumlah bank yang telah dipublikasikan pada Majalah Infobank dan sudah terdaftar di BEI juga sangat terbatas. Untuk penelitian selanjutnya, mungkin dapat menambah jumlah sampel dengan cara melakukan survei yang difokuskan untuk mengukur loyalitas nasabah pada bank yang sudah terdaftar di BEI. Melalui hasil survei tersebut, penelitian tidak hanya dapat dilakukan pada analisis level perusahaan saja, tetapi juga dapat dilakukan analisis pada level pelanggan dan level unit bisnis. 
Kedua, oleh karena data yang digunakan dalam penelitian ini terbatas, maka data diolah dan dianalisis dengan PLS menggunakan software SmartPLS 3 yang disinyalir memiliki kelemahan. Untuk penelitian selanjutnya, apabila dapat mengumpulkan data yang lebih banyak, masalah metode analisis ini dapat diatasi dengan Structural Equation Modeling (SEM).

Ketiga, di dalam periode penelitian yaitu tahun 2007 dan 2008, telah terjadi krisis global yang disinyalir berpengaruh terhadap kinerja perusahaan yang berada di industri perbankan Indonesia. Periode tersebut tidak dikontrol atau dikeluarkan dalam penelitian ini lantaran akan banyak data yang terbuang, mengingat jumlah sampel yang dimiliki sangat terbatas. Penelitian selanjutnya diharapkan mempertimbangkan dan mengontrol persoalan tersebut.

Implikasi penelitian ini bagi perusahaan yang berada dalam industri perbankan adalah diharapkan tidak hanya fokus untuk meningkatkan kepuasan nasabah saja, tetapi juga menjaga hubungan dan kemitraan dengan nasabahnya. Sesuai dengan hasil penelitian ini, hal tersebut disinyalir mampu meningkatkan loyalitas nasabah. Dengan loyalitas nasabah yang tinggi, maka kinerja perbankan (baik kinerja keuangan, kinerja pasar, maupun kinerja non-keuangannya) akan meningkat.

\section{DAFTAR PUSTAKA}

Beerli, A., Martin, J.D., \& Quintana, A. 2004. A Model of Customer Loyalty in the Retail Banking Market. European Journal of Marketing, 38(1/2).

Bolton, R.N., Kannan, P.K., \& Bramlett, M.D. 2000. Implications of Loyalty Program Membership and Service Experiences for Customer Retention and Value. Journal of the Academy of Marketing Science, 28(1): 95-108.

Caruana, A. 2002. Service Loyalty the Effects of Service Quality and the Mediating Role of Customer Satisfaction. European Journal of Marketing, 36(7/8).
Cooper, R. \& Kaplan, R.S. 1991. The Design of Cost Management Systems. New Jersey: Prentice Hall.

Fisher, J. 1992. Use of Non-Financial Performance Measures. Journal of Cost Management, 6: 31-38.

Fornell, C., Mithas, S., Morgeson III, F.V., \& Krishnan, M.S. 2006. Customer Satisfaction and Stock Prices: High Returns, Low Risk. Journal of Marketing, 70(1): 3-14.

Gani, L. \& Jermias, J. 2012. Effects of Strategy-Management Control System Misfits on Firm Performance. Accounting Perspectives/ Perspectives Compatibles, 11(3): 165-196.

Griffin, J. 2005. Customer Loyalty: Growing and Keeping Customers. San Fransisco: Jossey Bass.

Gronholdt, L., Martensen, A., \& Kristensen, K. 2000. The Relationship between Customer Satisfaction and Loyalty: Cross-Industry Differences. Total Quality Management, 11(4): 509-514.

Gupta, S. \& Zeithaml, V. 2006. Customer Metrics and Their Impact on Financial Performance. Marketing Science, 25(6): 718-739.

Hussein, A.S. 2015. Penelitian Bisnis dan Manajemen Menggunakan Partial Least Squares (PLS) dengan SmartPLS 3.0. Modul Ajar. Fakultas Ekonomi dan Bisnis Universitas Brawijaya.

Ittner, C.D. \& Larcker, D.F. 1998. Are Nonfinancial Measures Leading Indicators of Financial Performance? An Analysis of Customer Satisfaction. Journal of Accounting Research, 36: 1-35.

Johnson, H.T. \& Kaplan R.S. 1987. Relevance Lost: The Rise and Fall of Management Accounting. Boston: Harvard Business School Press.

Kaplan, R.S. \& Norton, D.P. 1996. The Balanced Scorecard: Translating Strategy into Action. Boston: Harvard Business School Press.

Kheng, L.L., Mahamad, O., Ramayah, T., \& Mosahab, R. 2010. The Impact of Service Quality on Consumer Loyalty: A Study of Bank in Penang, Malaysia. International Journal of Marketing Studies, 2(2): 5766.

Kotler, P. 2005. According to Kotler: The World's Foremost Authority on Marketing Answers Your Questions. New York: AMACOM. 
Leo, L., Gani, L., \& Jermias, J. 2009. Investigating the Impacts of Customer Satisfaction on Firm Performance. Gajah Mada International Journal of Business, 11(3): 341-359.

Majalah Infobank 394/XXXIII (Januari). 2012. Jakarta.

Majalah Infobank 406/XXXIV (Januari). 2013. Jakarta.

Majalah Infobank 418/XXXV (Januari). 2014. Jakarta.

Merchant, K.A. \& Van der Stede, W.A. 2007. Management Control Systems: Performance Measurement, Evaluation, and Incentive. New York: PrenticeHall.

Rhee, M. \& Mehra, S. 2006. Aligning Operations, Marketing, and Competitive Strategies to Enhance Performance: An Empirical Test in the Retail Banking Industry. Omega, 34(5): 505-515.

Reichheld, F.F. \& Sasser, Jr.W.E. 1990. Zero Detections: Quality Comes to Services. Harvard Business Review, 68(5): 105-110.
Siddiqi, K.O. 2011. Interrelations between Service Quality Attributes, Customer Satisfaction, and Customer Loyalty in the Retail Banking Sector in Bangladesh. International Journal of Business Management, 6(3): 12-36.

Simons, R. 1990. The Role of Management Control Systems in Creating Competitive Advantage: New Perspective. Accounting, Organizations, and Society, 15(1-2): 127-143.

Soeling, P.D. 2007. Pertumbuhan Bisnis dan Tanggung Jawab Sosial Perusahaan. Jurnal Ilmu Administrasi dan Organisasi, Bisnis, E Birokrasi, 15(1).

Venkatraman, N. \& Ramanujam, V. 1987. Measurement of Business Economic Performance: An Examination of Method Convergence. Journal of Management, 13(1): 109-122. 